ANUVA Volume 2 (1): 43-53, 2018

Copyright (02018, ISSN: 2598-3040 online

Available Online at: http://ejournal.undip.ac.id/index.php/anuva

\title{
Peluang dan Tantangan Penerapan Cloud Computing (Komputasi Awan) Sebagai Solusi Automasi Kerjasama Antar Perpustakaan
}

\author{
Lydia Christiani ${ }^{*}$ ) \\ ${ }^{1}$ Program Studi Ilmu Perpustakaan, Fakultas Ilmu Budaya, Universitas Diponegoro, \\ Jl. Prof. Soedarto, SH, Kampus Undip Tembalang, Semarang, Indonesia 50275
}

${ }^{*}$ Korespondensi: lydia.christiani@undip.ac.id

\begin{abstract}
[Title: Opportunities and Challenge of the Implementation of Cloud Computing as an automation solution in cooperation between libraries] Cloud computing is not something new. Nevertheless the potential utilization is not fully realized by the wider community, especially its potential to become a means of automation of cooperation between libraries. Availability of infrastructure vendors, web-based library software, to web browsers that have been popular among the community is the initial capital to implement cloud computing in various library services. Although on the other side, the library must face challenges such as the utilization of human resources in the library as a manager of the library system itself, as well as investment in the development of cloud computing platform. These challenges can be overcome by building cooperation, both internally with fellow libraries, as well as by encouraging government and enterprise support in the field of information and communication technology.
\end{abstract}

Keywords: Cloud Computing; opportunities; challenge; automation; cooperation between libraries

\begin{abstract}
Abstrak
Cloud Computing atau komputasi awan bukanlah sesuatu hal yang baru. Meskipun demikian potensi pemanfaatannya belum sepenuhnya disadari oleh masyarakat luas, terlebih potensinya untuk menjadi sarana automasi kerjasama antar perpustakaan. Ketersediaan vendor infrastruktur, software perpustakaan berbasis web, hingga web browser yang telah populer di kalangan masyarakat merupakan modal awal untuk mengimplementasikan komputasi awan pada berbagai layanan perpustakaan. Meskipun di lain sisi perpustakaan harus menghadapi tantangan seperti pendayagunaan SDM dalam perpustakaan sebagai pengelola sistem perpustakaan itu sendiri, serta investasi dalam pembangunan platform komputasi awan. Tantangan-tantangan tersebut dapat diatasi dengan membangun kerjasama, baik secara internal dengan sesama perpustakaan, maupun dengan mendorong dukungan pemerintah serta perusahaan-perusahaan dalam bidang teknologi informasi dan komunikasi.
\end{abstract}

Kata Kunci: Cloud Computing; peluang; tantangan; automasi; kerjasama antar perpustakaan

\section{Pendahuluan}

Dunia telah memasuki era informasi, sebuah era dimana infomasi dipandang sebagai sebuah kekuatan untuk mengaktualisasikan diri. Berbagai perubahan muncul seiring dengan perkembangan era informasi tersebut. Perubahan-perubahan tersebut juga telah turut serta memicu berbagai penemuan di dunia, terutama dalam bidang informasi, bahkan dua penemuan besar berhasil menjadi tonggak revolusi informasi dan komunikasi yang telah merubah wajah dunia informasi secara signifikan. Revolusi yang pertama ditandai dengan ditemukannya mesin cetak sedangkan revolusi yang kedua ditandai oleh 
penemuan komputer dan internet.

Komputer dan internet kini kian menjamur, bahkan telah menjadi gaya hidup di era informasi ini. Hampir setiap orang berinteraksi dengan komputer dan internet setiap harinya. Berbagai modifikasi fitur internet pun terus menerus berkembang, dari yang semula hanya mampu melakukan interaksi satu arah, kini telah berganti haluan dengan mode interaktif, yang memungkinkan interaksi dua arah atau yang lebih dikenal dengan konsep web 2.0 (Casey and Savastinuk, 2007).

Web 2.0 telah membuka berbagai peluang baru dalam berbagai aspek kehidupan, mulai dari aspek politik, ekonomi, hingga sosial budaya. Peluang tersebut juga telah menjadi perhatian perpustakaan sebagai salah satu lembaga penyedia informasi, munculnya konsep library 2.0 yang mengadaptasi konsep web 2.0 adalah salah satu implikasinya (Chowdurry and Chowdurry, 2003).

Kini web 2.0 telah berkembang lebih jauh lagi, dengan ciri kemampuan interaktifnya, web 2.0 memunculkan jaringan-jaringan sosial di dunia maya, baik tingkat personal, komunitas, maupun publik secara luas. Jejaring tersebut kini berkembang menjadi sebuah inovasi baru yang dijuluki komputasi awan (cloud computing).

Komputasi awan memberikan peluang interaksi dan jaringan kerja (networking) yang lebih luas. Hal ini memungkinkan kerjasama tingkat internasional sekalipun dapat dilakukan. Bagi perpustakaan, hal ini menjadi peluang besar yang telah diadopsi untuk menjalin kerjasama antar perpustakaan, bahkan hingga membangun konsep "cloud library" dimana seluruh perpustakaan di dunia berada di bawah sistem tersebut.

Bagi perpustakaan di Indonesia sendiri, automasi perpustakaan telah memasuki tahap library 2.0 dengan basis-basis open source yang mana telah siap untuk berkembang ke arah komputasi awan (Syaikhu, 2010). Tetapi, peluang inovasi ini sekaligus memberikan berbagai tantangan yang harus dihadapi oleh perpustakaan-perpustakaan di Indonesia untuk semakin membenahi program automasinya agar mampu memanfaatkan kehadiran inovasi komputasi awan secara maksimal bagi perkembangan automasi lembaga informasi di Indonesia, terutama bagi perpustakaan.

\section{Metode Penelitian}

Penulisan artikel ini menggunakan metode analisis deskriptif dalam pembahasannya. yaitu melakukan analisis terhadap sejumlah literatur serta sejumlah sumber data sekunder lainnya. Data-data yang diperoleh dari literature dan sumber sekunder tersebut dihubungkan dan dibandingkan secara teoritis dengan menggunakan teori-teori yang terkait dengan implementasi cloud computing bagi perpustakaan. Berdasarkan hasil analisis tersebut akan diketahui peluang dan tantangan penerapan cloud computing sebagai alternatif solusi automasi kerjasama layanan antar perpustakaan di Indonesia. Hasil dari analisis tersebut digunakan untuk mencari alternatif solusi untuk mengatasi tantangan penerapan cloud computing sebagai solusi automasi kerjasama antar perpustakaan di Indonesia. 


\section{Pembahasan}

\subsection{Pengertian Cloud Computing (Komputasi Awan)}

Cloud Computing (komputasi awan) adalah teknologi yang memanfaatkan layanan internet menggunakan pusat server yang bersifat virtual dengan tujuan pemeliharaan data dan aplikasi (Indra, 2010). Cloud (awan) merupakan metafora yang digunakan dalam dunia ilmu komputer untuk menggambarkan internet (Mell and Grance, 2009). Gumpalan awan (cloud) juga merupakan kata yang digunakan untuk menggambarkan infrastruktur kompleks tersembunyi yang merupakan suatu metode komputasi dimana kapabilitas terkait teknologi informasi dapat disajikan dalam suatu layanan yang dapat diakses penggunanya melalui internet tanpa memiliki kendali terhadap infrastruktur teknologi yang membantunya. Dengan kata lain komputasi awan adalah suatu paradigma dimana informasi disimpan secara permanen di internet dan tersimpan secara sementara di komputer pengguna (desktop, notebook, tablet, handphone, dsb.)

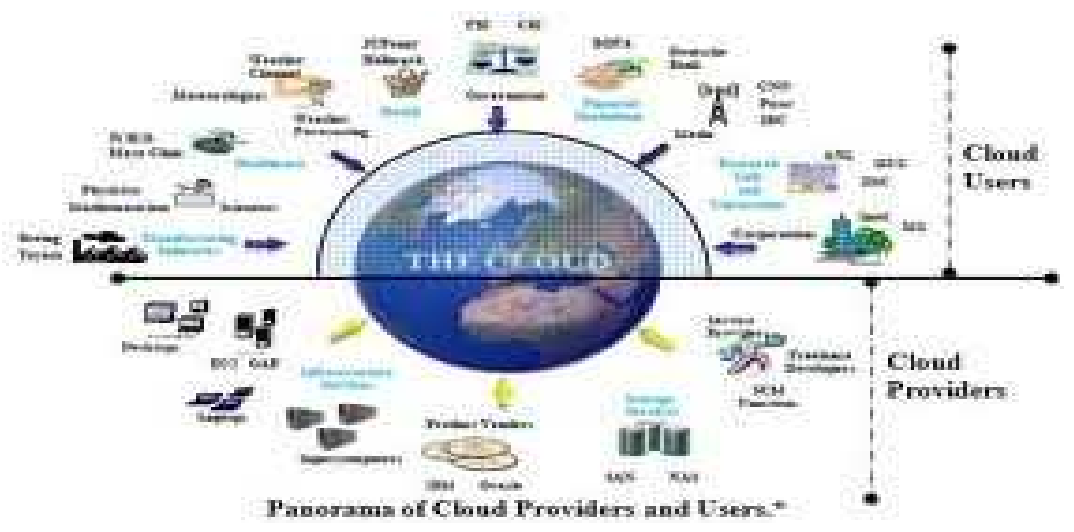

Gambar 1 Paradigma Cloud Computing (Mell and Grance, 2009)

Komputasi awan merupakan suatu konsep umum dari perkembangan web 2.0 yang disinergikan dengan komputer-komputer pengguna (device) dengan teknologi terbaru yang mampu mengakses internet kapanpun dan dimanapun, sehingga memampukan pengguna tetap berinteraksi dengan data dan dokumen mereka, dan di saat yang sama berbagi data dan dokumen tersebut dengan rekan mereka.

Komputasi awan memiliki beberapa sifat layanan, yaitu "on demand", elastic/ scalable, dan sepenuhnya dikelola oleh penyedia/ provider. Layanan yang bersifat "on demand" di sini memiliki arti bahwa pengguna layanan bebas memilih dan memanfaatkan layanan-layanan yang terdapat dalam komputasi awan. Sedangkan sifat elastis dan scalable disini berbicara tentang fleksibilitas kapasitas yang dapat diminta pengguna sewaktu-waktu dengan menggunakan besaran satuan kecepatan data tertentu per detik (kb/s, Mb/s, dsb.), sementara sifat layanannya yang terakhir adalah pengelolaan penuh oleh provider dengan maksud untuk meringankan pekerjaan pengguna dalam mengolah data dan dokumen serta berbagi dengan rekan-rekan mereka (Okuhara, Shiozaki, and Suzuki, 2010).

Komputasi awan terdiri dari tiga elemen dasar yang menyusunnya (Mitchell, 2010), yaitu 
Software as a Service (SaaS), Platform as a Service (PaaS), dan Infrastructure as a Service (IaaS). Elemen dasar yang pertama merupakan kemampuan yang diberikan pada pengguna untuk menggunakan aplikasi penyedia layanan (provider) dapat beroperasi dengan koneksi internet. Aplikasi dapat diakses oleh web browser dari perangkat pengguna, misalnya surat elektronik berbasis web. Sedangkan elemen dasar yang kedua merupakan kemampuan yang diberikan kepada pengguna untuk menyebarkan aplikasi yang dibuat oleh pengguna ke infrastruktur komputasi awan yang mendasari. Infrastruktur tersebut adalah jaringan, server, sistem operasi, penyimpanan, dan bahkan kemampuan aplikasi individu yang terbatas terhadap pengaturan konfigurasi aplikasi pengguna lainnya. Sementara elemen dasar yang ketiga merupakan kemampuan yang diberikan kepada pengguna untuk memproses, menyimpan, berjaringan, dan komputasi sumberdaya lain yang penting, dimana pengguna dapat menyebarluaskan dan menjalankan perangkat lunak secara bebas, dapat mencakup sitem operasi dan aplikasi. Pengguna tidak mengelola atau mengendalikan infrastruktur komputasi awan yang menjadi dasar sistem, tetapi memiliki kontrol terbatas atas sistem operasi, penyimpanan, aplikasi yang disebarkan, dan komponen jaringan yang dipilih, seperti firewall host misalnya, pada akun pengguna pada sistem komputasi awan.

Penyebaran komputasi awan sendiri terbagi menjadi empat area; yaitu private cloud, community cloud, public cloud, dan hybrid cloud. Pembagian ini didasarkan pada pengelola infrastruktur sistem komputasi awan. Pada private cloud pengelolaannya dilakukan oleh sebuah lembaga atau organisasi, pada community cloud pengelolaannya dilakukan oleh beberapa lembaga atau organisasi yang mendukung suatu komunitas tertentu, pada public cloud pengelolaannya dilakukan oleh kelompok industri besar yang menyediakan layanan komputasi awan bagi masyarakat luas, sedangkan hybrid cloud pengelolaannya dilakukan dengan memadukan dua atau lebih pengelolaan infrastruktur komputasi awan yang dilakukan pada private cloud, community cloud, maupun public cloud (Mohamidi, 2010).

Kehadiran konsep paradigma komputasi awan masih terus dikembangkan dan disempurnakan. Konsep baru ini menjanjikan masa depan yang lebih baik bagi dunia informasi, hal ini tentu menjadi tantangan bagi lembaga-lembaga penyedia informasi untuk menjalankan fungsinya sebagai provider dan pengelola infrastruktur komputasi awan, tentu saja termasuk perpustakaan, sebagai salah satu lembaga penyedia informasi.

\subsection{Pemanfaatan Komputasi Awan dalam Perpustakaan}

Paradigma komputasi awan mulai dikenal sejak tahun 2009. Kemunculan komputasi awan telah memberikan pengaruh yang besar pada dunia informasi, prinsip "dunia di tangan anda" benar-benar telah menjadi realitas, bahkan menjadi gaya hidup masyarakat. Hal ini tentu saja mengubah cara pandang orang-orang terhadap informasi, dan yang pada akhirnya juga mengubah cara orang memperoleh informasi itu sendiri.

Perpustakaan sebagai lembaga penyedia informasi tentu saja tidak dapat tinggal diam dengan adanya perubahan tersebut. Library of Congress telah mencoba mengambil langkah nyata menghadapi paradigma komputasi awan ini, dan terus mengimplementasikannya dalam penyelenggaraan layanan 
perpustakaan.

Komputasi awan menjanjikan penghematan dana pada pengembangan sistem automasi perpustakaan, dengan menggunakan basis open source dan ketersediaan utility serta aplikasi yang dimiliki bersama (share), hal tersebut menjadi pilihan terbaik untuk mengikuti perkembangan zaman informasi dengan tidak membutuhkan dana yang besar, karena dengan komputasi awan memungkinkan perpustakaan yang satu bekerjasama dengan perpustakaan yang lain dalam pemanfaatan dan pengelolaan sistem aplikasi yang sama, sehingga lebih mudah dilakukan (Tomaiuolo, 2004).

Dengan memanfaatkan social responsibility of the company dari perusahaan-perusahaan (Webber and Petters, 2010) yang menjadi vendor pemasok aplikasi teknologi informasi yang menjadi elemen komputasi awan seperti Google, Salesforce, Microsoft, Yahoo, Amazon, Zoho, dsb. Perpustakaan dapat menarik perhatian perusahaan-perusahaan tersebut untuk menjalin kerjasama dengan biaya yang rendah agar perusahaan-perusahaan tersebut mau memasok aplikasi fitur yang dibutuhkan bagi perpustakaan untuk memanfaatkan komputasi awan atau yang dikenal dengan "cloud library" .

Dengan memanfaatkan komputasi awan, perpustakaan lebih mampu menyelenggarakan layanan dengan menerapkan prinsip-prinsip berpusat pada pengguna, terbuka dan transparan, interoperability (kemampuan jalinan antar operasi), representatif, seimbang, dan menuju perubahan yang lebih baik. Dengan kata lain, komputasi awan mengakhiri masa perpustakaan sebagai lumbung-lumbung informasi yang terpisah dan tertutup satu sama lain serta membuka pintu seluas-luasnya untuk memulai era baru akses perpustakaan yang terbuka satu dengan lainnya, saling terhubung, dan saling menjadi partner langsung dalam melaksanakan automasi perpustakaan. Selain itu perpustakaan juga bisa berbagi konten perpustakaan secara langsung, seperti koleksi buku yang dimiliki, abstrak-abstrak buku-buku best-seller, bahkan juga informasi-informasi tentang koleksi-koleksi unik dan langka yang hanya dimiliki oleh suatu perpustakaan, dengan komputasi awan semua hal tersebut dapat didayagunakan bersama-sama, dengan melakukan kerjasama berbasis cloud library.

Pemanfaatan cloud library meliputi manajemen perpustakaan, pencarian koleksi dan fitur-fitur yang terdapat pada perpustakaan anggota cloud library, kolaborasi dan pengkreasian data-data perpustakaan, terutama yang menyangkut koleksi, serta sinkronisasi dan berbagi data pada sistem cloud library (Witten, Bainbridge, and Nichols, 2010). Manajemen perpustakaan dilakukan dengan memanfaatkan kerjasama jaringan LibLime, Polaris, OCLC, SirsiDynix, ExLibris. Pencarian data dilakukan dengan memanfaatkan kerjasama jaringan dengan Summon, Encore, AquaBrowsser, WorldCat, Google Scholar Beta, republiclibrary, Discovery Service. Kolaborasi dan pengkreasian data dilakukan dengan memanfaatkan kerjasama jaringan dengan Evernote, PBWorks, EtherPad, wetpaint, drop.io, wikia, dan Google docs beta. Sinkronisasi dan berbagi data dilakukan dengan memanfaatkan kerjasama jaringan dengan Dropbox, Live Mesh Beta, Dropbox, youSENDit, box, elephant drive, dan Jungle Disk.

Sedangkan untuk kepentingan publikasi dilakukan dengan dengan memanfaatkan kerjasama jaringan dengan Scribd, blurb, Blog, flickr, createspace, Lulu, dan Wikies. Sementara untuk keperluan interaksi menggunakan Facebook, meebo, flickr, google talk, yahoo messanger, AIM.Express, dan twitter. 
Sementara untuk tujuan khusus interaksi pembelajaran dan diskusi lebih cenderung memanfaatkan jaringan google docs. Dari segi pengguna, akses berbagai layanan tersebut, dapat diakses di mana saja dan kapan saja melalui device yang mereka miliki, dengan memanfaatkan operating system google chrome, chumby, mozilla firefox, amazon, republiclibrary dan safari (Fox, 2009).

\subsection{Implementasi Komputasi Awan bagi Perpustakaan di Indonesia}

Penerapan komputasi awan pada perpustakaan di Indonesia sendiri belum terlalu terimplementasi dengan maksimal, tetapi perkembangan ke arah tersebut mulai tampak. Adanya dukungan pemerintah terhadap perkembangan komputasi awan di Indonesia memberi angin segar bagi perkembangan teknologi ini. Implementasi komputasi awan sendiri saat ini masih dimanfaatkan sebatas pada sektor ekonomi yang mana terutama dalam ruang lingkup e-commerce. Namun, saat ini komputasi mulai merambah pemerintahan dengan memaksimalkan konsep e-government. Gejala yang tampak senada dengan perkembangan komputasi awan di dunia pada umumnya. Dari pemanfaatan dari sektor ekonomi, merambah ke sektor pemerintahan, yang kemudian menuju ke ranah pendidikan, dimana perpustakaan menjadi salah satu komponen dalam ranah pendidikan tersebut. Mengaca dari perkembangan komputasi awan di dunia, penerapan komputasi awan secara luas tinggal selangkah lagi, karena implementasi komputasi awan di Indonesia telah menjangkau pemerintahan negara ini. Hal ini mengindikasikan bahwa perusahaan-perusahaan vendor pemasok aplikasi teknologi komputasi awan telah siap bekerjasama dengan lembaga-lembaga non profit, seperti halnya pada lembaga-lembaga pemerintah dan tentu saja perpustakaan.

Perpustakaan sudah selayaknya mulai mempersiapkan diri untuk menerapkan komputasi awan dalam penyelenggaraan layanan perpustakaan. Mulai dari infrastruktur, keamanan data, hingga sumber daya manusia yang menjalankan sistem komputasi awan dalam perpustakaan itu sendiri. Hal inilah yang dilakukan oleh Pusat Perpustakaan dan Penyabaran Teknologi Pertanian (PUSTAKA).

PUSTAKA merupakan salah satu unit kerja di bawah Badan Penelitian dan Pengembangan Pertanian yang memiliki tugas pokok melaksanakan pengelolaan perpustakaan dan penyebarluasan informasi ilmu pengetahuan dan teknologi pertanian (Syaikhu, 2010). Perpustakan yang berada di lingkup Kementrian Pertanian ini memiliki ruang kerja yang luas, yaitu di seluruh Indonesia. Perpustakaan Unit Kerja (UK) atau Unit Pelayanan Teknis (UPT) yang tersebar di seluruh Indonesia menjadi suatu kendala tersendiri bagi PUSTAKA. Kehadiran inovasi komputasi awan menjadi solusi bagi PUSTAKA. Hal tersebut membuat PUSTAKA berani mengambil langkah untuk mempersiapkan infrastruktur, keamanan data, dan SDM yang siap mengimplementasikan komputasi awan dalam penyelenggaraan layanan informasi yang dilakukan oleh PUSTAKA.

Dalam hal mempersiapkan infrastruktur, PUSTAKA melakukan penyewaan jaringan internet dan juga mempersiapkan layanan Disaster Recovery Centre (DRC) untuk mengantisipasi gangguan pada pusat data seperti gangguan petir, cuaca buruk, bahkan bencana alam. Pada Platform as a Service (PaaS), PUSTAKA menyiapkan fasilitas yang diberikan pada Unit Kerja maupun Unit Pelaksana Teknis 
(UK/UPT) untuk menyebarkan aplikasi yang dibuat UK/UPT atau yang diperoleh pada infrastruktur komputasi awan menggunakan bahasa pemrograman dan peralatan yang didukung oleh provider. Hal ini dilakukan untuk mempermudah operasional pertukaran data dan informasi.

Sedangkan pada Software as a Service (SaaS), PUSTAKA menyediakan fasilitas-fasilitas aplikasi atau software yang berkaitan dengan perpustakaan, terutama bagi keperluan pengadaan, pengolahan, dan layanan; sehingga mudah dilakukan updating data. Selain itu PUSTAKA juga mempersiapkan web browser seperti e-mail berbasis web, yang memungkinkan pengguna mengakses informasi dari PUSTAKA melalui berbagai device (perangkat) yang digunakan pengguna.

Dalam hal keamanan data PUSTAKA mempersiapkan diri untuk mengadopsi konsep keamanan layanan komputasi awan Fujitsu yang disebut dengan "trusted-service Platform". Konsep tersebut melindungi keamanan data dengan membangun pemisahan secara logis dari jaringan, operating system, dan lapisan data melalui teknologi virtualisasi. Konsep ini mudah untuk diadopsi dan cukup sederhana untuk back up keamanan data. Pusat data terbagi menjadi tiga tempat penyimpanan virtual, yaitu Virtual Storage yang menyimpan data-data enkripsi, Virtual Servers yang menyimpan jaringan-jaringan enkripsi, dan Virtual Networks yang menyimpan terminal authentication/ approval.

Sedangkan untuk sumberdaya manusia (SDM) sendiri, PUSTAKA menambahkan 2 orang programmer, 1 orang networking, dan 1 orang multimedia. Kompetensi yang dimiliki tenaga-tenaga dengan kualifikasi spesialis di bidang teknologi informasi ini diharapkan mampu membantu PUSTAKA memanfaatkan komputasi awan dalam menyelenggarakan layanannya. Selain penambahan personil SDM, PUSTAKA juga mengadakan pelatihan secara berkala bagi seluruh staff untuk mengubah pola pikir lama dan mampu beradaptasi dengan paradigma komputasi awan sehingga segenap SDM PUSTAKA dapat bekerja secara terintegrasi.

Hal yang dilakukan oleh PUSTAKA menegaskan pentingnya penerapan komputasi awan bagi perpustakaan, terutama sebagai solusi automasi kerjasama antar perpustakaan. Dengan penerapan komputasi awan, perpustakaan lebih menghemat biaya dalam menyelenggarakan layanan maupun menerapkan automasi perpustakaan terutama di bidang kerjasama antar perpustakaan, saling melengkapi informasi yang dimiliki masing-masing perpustakaan, serta lebih mudah terhubung satu dengan yang lainnya.

\subsection{Peluang dan Tantangan Pemanfaatan Komputasi Awan bagi Masa Depan Automasi Kerjasama Antar Perpustakaan di Indonesia}

Komputasi awan menjanjikan peluang yang besar bagi perkembangan automasi perpustakaan di Indonesia. Dengan konsep "easier to share" yang menjadi tema utama inovasi teknologi informasi ini, diharapkan mampu untuk membuka jaringan kerja yang lebih luas dan lebih memungkinkan untuk dilakukan.

Pemanfaatan komputasi awan bagi perpustakaan di Indonesia sendiri masih sebatas persiapan pembangunan infrastruktur yang menjadi platform utama komputasi awan. Namun, perkembangan 
teknologi informasi di Indonesia sangat memungkinkan bagi perpustakaan untuk sesegera mungkin mengimplementasikan komputasi awan bagi penyelenggaraan perpustakaan, terutama dalam hal kerjasama antar perpustakaan.

Komputasi awan bukanlah konsep utopia bagi perpustakaan di Indonesia. Vendor sistem operasi yang kompatibel bagi komputasi awan seperti Windows Azure dan Ubuntu enterprise cloud telah hadir di Indonesia. Software Management System seperti SlimS, openbiblio, PMB, koha, newgenlib, evergreen, dsb. merupakan software populer yang dipakai dalam automasi perpustakaan. Sotware tersebut juga telah dirancang berbasiskan web, sehingga hal tersebut menjadi potensi bagi Sotware as a Service (SaaS) dalam komputasi awan. Selain itu, web browser seperti google chrome, mozilla firefox dan safari merupakan web browser yang lazim dimanfaatkan di Indonesia, sehingga pengguna perpustakaan yang ingin mengakses layanan di perpustakaan melalui perangkat (device) yang mereka gunakan mampu melakukan akses. Potensi-potensi teknis tersebut akan memampukan perpustakaan mengimplementasikan komputasi awan, terlebih dengan pemanfaatan FLOSS (Free Libre Open Source Software) yang dapat mendukung perpustakaan untuk membangun sistem cloud atau komputasi berbasis web dengan hanya menyediakan infrastruktur sendiri dengan cara yang sederhana.

Dengan mengimplementasikan komputasi awan, perpustakaan dapat menerapkannya pada berbagai layanan, seperti layanan referens (reference services), layanan peminjaman, layanan webinar, layanan membaca, layanan on-line storage, dsb. Sebagai contoh nyata pelaksanaannya, anggota perpustakaan dapat bertanya melalui widget yahoo messanger atau form request yang disediakan oleh library portal dalam layanan referens, anggota perpustakaan dapat memperpanjang dan memesan koleksi serta mengetahui status peminjaman dalam layanan peminjaman, perpustakaan dapat melakukan user education melalui webinar (seminar berbasis web) dengan para anggota perpustakaan, perpustakaan dapat menyediakan layanan e-books yang bisa dibaca oleh anggota perpustakaan setelah login serta memberikan akses kepada anggota untuk menyimpan, mengelola, dan berbagi pakai file secara on-line, dsb.

Berbagai potensi manfaat dan pengembangan automasi perpustakaan melalui pengimplementasian komputasi awan memang sangat menjanjikan. Namun, selalu ada tantangan dibalik setiap peluang. Salah satu tantangan terbesar yang dihadapi perpustakaan dalam mengadopsi komputasi awan dalam menyelenggarakan berbagai layanannya adalah pola pikir SDM yang terdapat di perpustakaan itu sendiri. Setiap perubahan selalu mendatangkan rasa ketidaknyamanan akan perubahan itu sendiri. Pada sisi inilah diperlukan penyuluhan yang lebih intens tentang seluk beluk dari komputasi awan itu sendiri, sehingga SDM dalam perpustakaan siap mengadopsi perubahan perkembangan teknologi ini menjadi suatu peluang untuk memajukan perkembangan automasi perpustakaan, sehingga perpustakaan bisa menghadirkan layanan yang lebih baik. Selain itu penyuluhan yang diberikan juga harus mampu membantu mengubah pola pikir SDM yang semula lekat dengan konsep automasi "membeli" menjadi "menyewa". 
Selain faktor SDM, perpustakaan juga perlu mengatasi tantangan investasi awal untuk membangun platform komputasi awan, yang merupakan gabungan dari infrastruktur jaringan, hardware, dan software. Perpustakaan juga perlu untuk turut mendorong pemerintah dalam pengembangan komputasi awan bagi perpustakaan demi terciptanya pemerataan distribusi informasi di seluruh Indonesia, terutama menyangkut permasalahan kesenjangan pembangunan bandwitdh di wilayah Indonesia bagian timur.

Bertolak dari pengalaman-pengalaman perpustakaan di negara lain dalam menghadirkan komputasi awan dalam penyelenggaraan perpustakaan serta berkaca pada perkembangan komputasi awan dalam dimensi ekonomi di Indonesia, kerjasama adalah kunci utama untuk mengatasi berbagai tantangan yang dihadapi dalam mengimplementasikan komputasi awan. Kerjasama antara pemerintah sebagai pembuat kebijakan, perusahaan telekomunikasi sebagai pembangun jaringan bandwidth, vendor aplikasi jaringan, operating system, dan juga software.

Perpustakaan harus dapat bekerjasama, baik secara internal dalam hal automasi perpustakaan, terutama dalam kerjasama konten lokal dalam bidang perpustakaan yang meliputi pelaksanaan manajemen perpustakaan hingga berbagi pakai antar perpustakaan, maupun secara eksternal dengan pihak-pihak di luar perpustakaan, seperti halnya pemerintah serta perusahaan-perusahaan yang bergerak dalam bidang teknologi informasi dan komunikasi.

\section{Simpulan}

Cloud Computing (komputasi awan) memberikan peluang baru bagi dunia informasi untuk memperluas cakrawalanya. Inovasi teknologi ini juga menjadi paradigma baru dalam hal pemanfaatan komputasi dalam berbagai bidang dalam kehidupan, mulai dari segi politik, ekonomi, hingga sosialbudaya. Perkembangan baru ini juga telah mengubah cara pandang masyarakat terhadap informasi, terlebih di era informasi ini, dimana informasi dipandang sebagai cara hidup (lifestyle) bagi sebagian besar orang terutama bagi mereka yang hidup mengandalkan informasi.

Masyarakat menuntut akses yang semakin cepat dan luas. Inovasi komputasi awan hadir sebagai solusi dari permasalahan tersebut. Dengan memanfaatkan komputasi awan, akses informasi yang lebih cepat dan lebih luas dapat diperoleh. Paradigma komputasi awan ini tentu memberi dampak yang besar bagi dunia informasi, tidak hanya bagi para konsumen/ pengguna informasi, tetapi juga bagi lembaga-lembaga penyedia informasi, di mana perpustakaan merupakan salah satunya. Lembaga-lembaga penyedia informasi mulai berbenah diri mengadopsi inovasi komputasi awan ini bagi ketersediaan informasi yang lebih memadai bagi penggunanya. Demikian pula halnya dengan perpustakaan.

Perpustakaan di Indonesia secara teknis telah memiliki potensi yang besar untuk melangkah ke arah komputasi awan. Mulai dari ketersediaan vendor infrastruktur, software perpustakaan berbasis web, hingga web browser yang telah populer di kalangan masyarakat. Hal ini merupakan modal awal yang cukup besar untuk mengimplementasikan komputasi awan pada berbagai layanan perpustakaan.

Meskipun demikian, perpustakaan perlu menghadapi berbagai tantangan seperti pendayagunaan 
SDM dalam perpustakaan sebagai pengelola sistem perpustakaan itu sendiri, serta investasi-investasi awal dalam pembangunan platform bagi komputasi awan. Tantangan-tantangan tersebut dapat diatasi dengan membangun kerjasama, baik secara internal dengan sesama perpustakaan, maupun dengan mendorong dukungan pemerintah serta perusahaan-perusahaan dalam bidang teknologi informasi dan komunikasi.

Dengan jalinan kerjasama yang kuat, perpustakaan memiliki potensi yang besar dalam mengimplementasikan komputasi awan pada seluruh jaringan informasi, terutama bagi seluruh perpustakaan di Indonesia. Dengan ancangan yang cermat dan menyeluruh dalam pembangunan infrastruktur, keamanan data, dan pendayagunaan SDM, perpustakaan dapat memaksimalkan pemanfaatan komputasi awan sebagai solusi kerjasama antar perpustakaan sehingga mampu menyediakan layanan informasi dengan akses yang lebih cepat dan lebih luas sesuai dengan kebutuhan informasi pengguna.

\section{Daftar Pustaka}

Casey, Michael E. And Savastinuk, Laura C. 2007. Library 2.0: A Guide to Participatory Library Service. New Jersey: Information Today Inc.

Chowdhury, G.G. And Chowdhury, Sudatta. 2003. Introduction to Digital Libraries. London: Facet Publishing

Fox, Robert. 2009. Library in The Clouds. Bangley: Emerald Group Publishing Limited

Indra, Didi. 2010. Definisi Komputasi Awan (Cloud Computing). Tersedia dalam http://community.gunadarma.ac.id/ [Diakses pada 23 Oktober 2011]

Mell, P and Grance T. 2009. NIST Definition of Cloud Computing v15. Tersedia dalam http://csrc.nist.gov/groups/SNS/cloud-computing/cloud-def-v-15.doc [Diakses pada 30 Oktober 2011]

.2009. Presentation on Effectively and Securely Using The Cloud Computing Paradigm v26. Tersedia dalam http://csrs.nist.gov/groups/SNS/cloud-computing/cloud-computing-v26.ppt [Diakses pada 30 Oktober 2011]

Mitchell, Erik. 2010. Using Cloud Services for Library IT Infrastructure dalam code4lib Journal. Tersedia dalam http://journal.code4lib.org/articles/2510. [Diakses pada 29 Oktober 2011]

Mohamidi, Adnuri. 2010. Cloud Computing, Konservatif dan Ideal. Tersedia dalam http://openlib.net/2010/04/cloud-computing-konservatif-dan-ideal/ [Diakses pada 22 Oktober 2011]

Okuhara, M; Shiozaki, T; and Suzuki, T. 2010. "Security Architecture for Cloud Computing" dalam FUJITSU Sci. Tech. J. v.46 (4): p. 397-402. Tersedia dalam http://www.fujitsu.com/downloads/MAG/vol46-4 [Diakses pada 30 Oktober 2011]

Syaikhu, Akhmad. 2010. "Komputasi Awan (Cloud Computing) Perpustakaan Pertanian" dalam Jurnal Pustakawan Indonesia Vol. 10 No.1. Tersedia dalam http://repository.ipb.ac.id [Diakses pada 22 Oktober 2011]

Tomaiuolo, Nicholas G. 2004. The Web Library: Building a World Class Personal Library with Free Web 
Resources. New Jersey: Information Today, Inc

Witten, Ian H; Bainbridge, David; and Nichols, David M. 2010. How to Build a Digital Library. Burlington: Elsevier

Webber, Desiree and Peters, Andrew. 2010. Integrated Library System: Planning, Selecting, and Implementing. California: ABC-CLIO, LLC 